\title{
IMMUNITY BOOSTERS TO COMBAT COVID-19 PANDEMIC
}

\author{
Vikram Kannamreddy* ${ }^{1}$, M. Jeeva ${ }^{1}$, Girija Prasad Patnaik ${ }^{1}$, R. Narmadha ${ }^{1}$, \\ P. L. Sai Linga Reddy ${ }^{2}$, B. Tarun Reddy ${ }^{3}$, D. Santhoshkumar ${ }^{1}$
}

${ }^{1}$ Department of Agronomy, Tamil Nadu Agricultural University, Coimbatore, India

${ }^{2}$ Department of Agronomy, RPCAU, Pusa, Bihar, India

${ }^{3}$ Department of Plant Breeding and Genetics, PAJANCOA \& RI, Karaikal, India

Received - September 25, 2020; Revision - October 25, 2020; Accepted - October 30, 2020

Available Online - October 31, 2020

DOI: http://dx.doi.org/10.18006/2020.8(Spl-1-SARS-CoV-2).S119.S125

KEYWORDS
Corona virus
Immmunity boosters
Kabasura kudineer
Septilin

\begin{abstract}
Corona virus disease 2019 (COVID-19) pandemic is caused by SARS-CoV2 (Severe Acute Respiratory Syndrome Coronavirus-2). It primarily targets lung epithelial cells of human respiratory system. The original strain of coronavirus was first identified at the end of December 2019 and emerged during an outbreak in Wuhan, China. The SARS-CoV-2 infection is mostly seen in the people with weak immune system. There are different ex-situ approaches to prevent the infection of corona virus viz., use of masks, sanitizing body and surfaces and maintaining social distance. But apart from them, in-situ prevention approaches like inclusion of nutrient rich healthy foods and herbs in daily diet helps to protect the body from inside by strengthening immune system. Thus, to strengthen immune system from inside we need to take immunity boosters, apart from normal healthy diet. These immunity boosters are prepared from leaves, roots, stems, flowers, barks and some other parts of medicinal and spice crops. These contain a mixture of proteins and other organic chemicals and carbohydrates, which include alkaloids, flavoids, glycosides, saponins, and terpenes. Kabasura kudineer, Nilavembu kudineer, Immuplus, Echinacea liquid, Immusarc, Septilin and immunity plus are some of the important immunotonics to strengthen and to protect body from infections and safeguard health. In this context we have to supplement our body with these immunity boosters to fight against not only COVID-19 but also other diseases.
\end{abstract}

* Corresponding author

E-mail: vikramreddy2882@gmail.com _Vikram Kannamreddy)

Peer review under responsibility of Journal of Experimental Biology and Agricultural Sciences.

Production and Hosting by Horizon Publisher India [HPI] (http://www.horizonpublisherindia.in/).

All rights reserved.
All the articles published by Journal of Experimental Biology and Agricultural Sciences are licensed under a Creative Commons Attribution-NonCommercial 4.0 International License Based on a work at www.jebas.org.

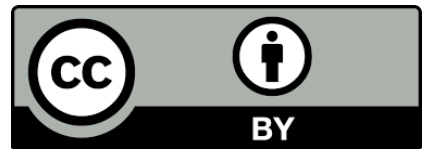




\section{Introduction}

Coronavirus belongs to the genus betacoronavirus and subfamily orthocoronavirinae, which infects humans, bats and wild animals (Tiwari et al., 2020; Zhu et al., 2020). It primarily targets the human respiratory system. Coronavirus disease 2019 (COVID-19) is caused by severe acute respiratory syndrome coronavirus -2 (SARS-CoV-2) which has emerged as a novel coronavirus from Wuhan, China in December 2019. The virus got rapidly spread to more than 215 countries, and is currently posing a pandemic having high global threats and challenges while affecting more than 43 million people with causing 1.16 million deaths as of $26^{\text {th }}$ October, 2020 (Ciotti et al., 2020; Dhama et al., 2020; Malik et al., 2020; Rodriguez-Morales et al., 2020; Rothan \& Byrareddy, 2020). Lung epithelial cells are the primary target of the virus through angiotensin-converting enzyme 2 (ACE2) receptor (Wan et al., 2020). The term coronavirus was coined from the Latin word corona that means "crown" like shape (Rabi et al., 2020). The suffix 2019 novel coronavirus or "2019-nCoV" coronavirus was given by WHO on 12 January 2020. SARS-CoV-2 transmission is via human-to-human, mainly through direct contact and/or by contact with the infected surface with touching of the face. Additionally, it also spreads through respiratory droplets released by coughs or sneezes (Peng et al., 2020). The symptoms of SARS-CoV2 infection appear after an incubation period of approximately 5.2 days (Bai et al., 2020). The most common symptoms at onset of COVID-19 are fever, cough, and fatigue, while other symptoms include headache, haemoptysis, diarrhoea and lymphopenia (Ren et al., 2020; Huang et al., 2020; Wang et al., 2020).

The initial death cases of COVID-19 outbreak occurred primarily in elderly people, possibly due to a weak immune system that permits faster development of viral infection (Wang et al., 2020; Li et al., 2020a). Covid-19 attacks people with low immune systems and especially of under and over ages. The immune system is built on beneficial live bacteria that live in the gut which protect the human body from various diseases. When the immune system response is low, weak, or damaged it becomes an open invitation for infections such as coronavirus or other diseases (Arshad et al., 2020). So strengthening immune system naturally is the correct way to fight against this pandemic viral disease.

India is the mother land for medicinal herbs and spices. Out of 21,000 medicinal plant species listed by WHO, 2500 species were native to India. Hence India is considered as botanical garden of the world (Mahima et al., 2012). The herbal extracts contain a mixture of proteins, organic chemicals and carbohydrates which include alkaloids, flavoids, flavonoids, polyphenols, glycosides, saponins, and terpenes which possess potent antiviral potential including against SARS-CoV-2 (Quan et al., 2007; Dhama et al., 2018; Tiwari et al., 2018; Ghosh et al., 2020; Bhowmik et al., 2020; Devanssh, 2020; Gangal et al., 2020; Mani et al., 2020; Ngwa et al., 2020).
Herbs and spices could be used as dietary or complementary therapy to prevent infection and to boost immunity (Dhama et al., 2018; Tiwari et al., 2018). Although the detailed molecular mechanisms associated with spices and immunity are not fully understood, spice consumption plays a role in our ability to fight COVID-19 (Infusino et al., 2020; Panyod et al., 2020; Elsayed \& Khan, 2020). Herbal extracts increase and help the intestinal beneficial bacteria, and the overall gut microbiome health which makes up to $85 \%$ of the body's immune system. Herbal supplements used as immune boosters are taken for prevention of seasonal infections such as colds and flu (Daneshmehr, 2016). In addition, immune boosters are recommended as supplements to the people with weak immune system (Peltzer et al., 2008; Tiwari et al., 2018).

Herbs useful for the immune system can be categorized into 2 groups: (1) herbs for immune system maintenance and (2) herbs for the treatment of immune system disorders. The herbs listed in the first category are immunotonics. The phytoconstituents of those immunotonics are known to exert an overall balancing effect on the immune system. Immunomodulators may be defined as a substance of biological or synthetic origin which has the ability to stimulate, suppress or modulate any of the components of the immune system (Dhama et al., 2015). The basic function of the immune system is largely to protect the individual against infectious agents and potential pathogens (Divya et al., 2020).

Leaves, roots, stems, flowers, barks and some other parts of medicinal and spice crops are used to prepare immunity boosting tonics. Some of the important tonics or extracts used as immunomodulators are Kabasura kudineer, Nilavembu kudineer, Immuplus, Echinacea liquid, Immusarc, Septilin and immunity plus (Tiwari et al., 2018; Mekala \& Murthy, 2020; Krupanithi et al., 2020; Tripathi et al., 2020). The prime aim of this review is to highlight about the importance of herbs and spices as immunity boosters to get rid of diseases including COVID-19 and safeguard health during the ongoing pandemic.

\section{Immunity booster's herbs and spices}

\subsection{Kabasura kudineer}

It is an ancient siddha medicine prepared from fifteen herbal extracts (Table 1) of equal proportion. This tonic was found to contain alkaloids, carbohydrates, glycosides, cardiac glycosides, flavonoids, phenols, saponins, hydrolysable tannins and terpenoids whereas Nilavembu kudineer choornam possessed alkaloids, carbohydrates, glycosides, flavonoids, phenols, tannin and terpenoids (Pitchiah et al., 2020; Panyod et al., 2020; Mekala \& Murthy, 2020). 
Table 1: Composition of Kabasura Kudineer

\begin{tabular}{|cccc|}
\hline S. No. & Botanical name & Common name & Part \\
\hline 1 & Zingiber officinale & Ginger & Fruit \\
\hline 2 & Piper longum & Long pepper & Flower bud \\
\hline 3 & Syzygium aromaticum & Clove & Root \\
\hline 4 & Tragia involucrate & Indian stinging nettle & Root \\
\hline 5 & Anacyclus pyrethrum & Mount atlas daisy & Root \\
\hline 6 & Hygrophila auriculate & Marsh barbel & Fruit rind \\
\hline 7 & Terminalia chebula & Chebulic myrobalan & Leaf \\
\hline 8 & Justicia adhatoda & Malabar nut & Leaf \\
\hline 9 & Coleus aromaticus & Indian mint & Root \\
\hline 10 & Costus speciosus & Creep ginger & Leaf, Stem \\
\hline 11 & Tinospora cordifolia & Reot \\
\hline 12 & Clerodendron serratum & Blue fountain bush & Whole plant \\
\hline 13 & Andrographis paniculata & Green chiretta or king of bitter & Root \\
\hline 14 & Sida acuta & Wireweed & Root tuber \\
\hline 15 & Cyperus rotundus & Nut grass & \\
\hline
\end{tabular}

Table 2: Composition of Nilavembu Kudineer

\begin{tabular}{|cccc|}
\hline S. No. & Botanical name & Common name & Part \\
\hline 1 & Andrographis paniculate & Green chiretta & Whole plant \\
\hline 2 & Chrysopogon zizanoides & Vettiver & Root \\
\hline 3 & Santalum album & Sandalwood & Rhizome \\
\hline 4 & Zingiber officinale & Ginger & Fruit \\
\hline 5 & Piper nigrum & Black pepper & Root tuber \\
\hline 6 & Cyperus rotundus & Nut grass & Whole plant \\
\hline 7 & Mollugo cerviana & Carpetweed & Root \\
\hline 8 & Plectranthus vettiveroides & Hrivera & Whole plant \\
\hline 9 & Trichosanthes cucumerina & Snake gourd &
\end{tabular}

\subsection{Nilavembu kudineer}

It is a polyherbal siddha formulation mainly consists of the king of bitter (Andrographis paniculate) and another 8 species of herbs (Table 2) (Christian et al., 2015). Nilavembu kudineer tonic contain alkaloids, carbohydrates, glycosides, flavonoids, phenols, tannins and terpenoids which are helpful in strengthening immunity and supports overall body health (Mekala \& Murthy, 2020; Panyod et al., 2020).

\subsection{Immuplus}

It is prepared by using Withania somnifera (Ashwagandha - roots), Tinospora cordifolia (Giloy - leaves), Ocimum santum (Basil - leaves) and Emblica officinalis (Amla - friut). It acts as immunomodulator and is a good source of antioxidants (Cecchini et al., 2014; Tiwari et al., 2018; Krupanidhi et al., 2020; Tripathi et al., 2020).

\subsection{Echinacea liquid}

Echinacea purpurea (Purple cone) stimulates the immune system, leading to renewed interest for treating immune deficiencies, "boosting" immune systems during periods of stress or pandemic, anxiety and inflammation. It has ability to mobilize leukocytes, activate phagocytosis and stimulate fibroblast formation. It is used to relieve problems of respiratory tract (Manayi et al., 2015; Divya et al., 2020). 


\subsection{Immusarc}

It is a herbal preparation from Withania somnifera and Emblica officinalis that helps to achieve optimum immune effectiveness (Chikhale et al., 2020; Tripathi et al., 2020).

\subsection{Septilin}

Septilin is made of Commiphora wightii (Bdellium tree), Glycyrrhiza glabra (Liquorice), Tinospora cordifolia (Giloy), Rubia cardifolia (Indian madder), Moringa pterygosperma (Drumstick) and Emblica officinalis (Amla) (Bailly \& Vergoten, 2020; Daswani \& Yegnanarayan, 2002). Septilin's immunomodulatory, antioxidant, anti-inflammatory and antimicrobial properties are beneficial in maintaining general wellbeing. It helps in elevating the body's resistance to infection. Septilin stimulates phagocytosis (elimination of bacteria through ingestion) by macrophage (white blood cells) activation, which combats infection. It is also beneficial in respiratory tract infections including chronic tonsillitis, pharyngitis, chronic bronchitis, nasal catarrh (mucous membrane inflammation of the respiratory tract) and laryngitis (Sandeep et al., 2011; Krupanidhi et al., 2020).

\subsection{Immunity Plus}

It is prepared from Echinacea purpurea (Purple cone), Hypoxis hemerocallidea (Africanpotato), Agothosma betulina (buchu), Mentha piperita (Peppermint), Solidago virgaurea (Wound wort), Viscum album (mistletoe), Crataegus oxycanthoides (Hawthorn), Schizandra chinesis (Five flavor berry), Astralagus membranaceus (Milkvetch), Olea europea (Olive leaf) and Propolis (Hlengwa et al., 2020). This affect various CYP enzymes including CYP3A4 and CYP2C9 and strengthens immune system (Awortwe et al., 2015; Elsayed \& Khan, 2020).

The above mentioned immune boosters act as immunomodulators or immunotonics. But to maintain immune system perfectly for longer period we need to take well-balanced, healthy diet which consists of medicinal herbs, vitamin A, C, D and E rich foods (Rahal et al., 2014; Chen et al., 2020; Panyod et al., 2020). Natural productderived phytochemicals, herbs, ayurvedic and traditional medicines are gaining importance owing to their promising anti-SARS-CoV-2 potential ( Donma \& Donma, 2020; Gangal et al., 2020; Gupta et al., 2020; Jahan \& Onay, 2020; Li et al., 2020b; Mani et al., 2020; Rastogi et al., 2020; Xu \& Zhang, 2020; Zhang et al., 2020a, 2020b). Avoiding junk food is much important to maintain overall health and immunity (Join \& Calendar, 2020). Also, proteinaceous foods are must in the daily diet (Hyman, 2020).

\section{Conclusion and future view}

Coronavirus is mostly affecting the people with low immune power and with multiple diseases like Diabetic mellitus and respiratory disorders. Even though there are different ex-situ approaches to prevent the infection of corona virus viz., use of masks, sanitizing body and surfaces and maintaining social distance. But apart from them, in-situ prevention approaches like inclusion of nutrient rich healthy food and herbs in daily diet helps to protect the body from inside. Herbal extracts of medicinal crops and spices like Kabasura kudineer, Nilavembu kudineer, Immuplus, Echinacea liquid, Immusarc, Septilin and immunity plus helps in maintaining immunity and also in proper functioning of the body. In this view apart from normal healthy diet which contains more proteins, vitamins and minerals we have to supplement our body with the above mentioned immunity boosters to fight against not only COVID-19 but also other diseases.

\section{Author contributions}

All the authors substantially contributed to the conception, compilation of data, checking and approving the final version of the manuscript, and agree to be accountable for its contents.

\section{Acknowledgments}

All the authors acknowledge and thank their respective Institutes and Universities.

\section{Funding}

This compilation is a review article written by its authors and required no substantial funding to be stated.

\section{Disclosure statement}

All authors declare that there exist no commercial or financial relationships that could, in any way, lead to a potential conflict of interest.

\section{References}

Arshad MS, Khan U, Sadiq A, Khalid W, Hussain M, Yasmeen A, Rehana H (2020) Coronavirus disease (COVID-19) and immunity booster green foods: A mini review. Food Science \& Nutrition 8(8): 3971-3976.

Awortwe C, Manda VK, Avonto C, Khan SI, Khan IA, Walker LA, Rosenkranz B (2015) Echinacea purpurea up-regulates CYP1A2, CYP3A4 and MDR1 gene expression by activation of pregnane $X$ receptor pathway. Xenobiotica 45(3): 218-229.

Bai Y, Yao L, Wei T, Tian F, Jin DY, Chen L, Wang M (2020) Presumed asymptomatic carrier transmission of COVID-19. Jama 323(14): 1406-1407.

Bailly C, Vergoten G (2020) Glycyrrhizin: An alternative drug for the treatment of COVID-19 infection and the associated respiratory syndrome? Pharmacology \& Therapeutics 107618. 
Bhowmik D, Nandi R, Kumar D (2020) Evaluation of Flavonoids as 2019-nCoV Cell Entry Inhibitor Through Molecular Docking and Pharmacological Analysis. Preprint Chem Rxiv. : 10.26434/chemrxiv.12071508.v

Cecchini S, Paciolla M, Caputo AR, Bavoso A (2014) Antioxidant potential of the polyherbal formulation "ImmuPlus": a nutritional supplement for horses. Veterinary Medicine International 2014:434239. doi: 10.1155/2014/434239.

Chen L, Hu C, Hood M, Zhang X, Zhang L, Kan J, Du J (2020) A Novel Combination of Vitamin C, Curcumin and Glycyrrhizic Acid Potentially Regulates Immune and Inflammatory Response Associated with Coronavirus Infections: A Perspective from System Biology Analysis. Nutrients 12(4):1193. doi: 10.3390/nu12041193.

Chikhale RV, Gurav SS, Patil RB, Sinha SK, Prasad SK, Shakya A, Prasad RS (2020) Sars-cov-2 host entry and replication inhibitors from Indian ginseng: an in-silico approach. Journal of Biomolecular Structure and Dynamics, 1-12. doi: 10.1080/07391102.2020.1778539.

Christian GJ, Subramanian M, Periyasami D, Manickavasakam K, Gunasekaran P, Sivasubramanian S, Nijavizhi M (2015) Protective Effect of Polyherbal Siddha Formulation-Nilavembu Kudineer against Common Viral Fevers Including Dengue-A Case-Control Approach. International journal of Pharmaceutical Sciences and Research 6(4): 1656.

Ciotti M, Ciccozzi M, Terrinoni A, Jiang WC, Wang CB, Bernardini S (2020) The COVID-19 pandemic. Critical Reviews in Clinical Labortatory Sciences 57(6):365-388.

Daneshmehr MA (2016) Herbal immune boosters: Valuable preventive means for international travelers flu: Lung \& Respiratory Care, Manchester, United Kingdom.

Daswani BR, Yegnanarayan R (2002) Immunomodulatory activity of septilin, a polyherbal preparation. Phytotherapy Research: An International Journal Devoted to Pharmacological and Toxicological Evaluation of Natural Product Derivatives, 16(2), 162-165.

Devanssh (2020) Possible Plant Based Medicines And Phytochemicals To Be Cure For Deadly Coronavirus COVID 19. World Journal of Pharmacy And Pharmaceutical Sciences 9: 531-533.

Dhama K, Karthik K, Khandia R, Munjal A, Tiwari R, Rana R, Khurana SK, Sana Ullah, Khan RU, Alagawany M, Farag MR, Dadar M, Joshi SK (2018) Medicinal and therapeutic potential of herbs and plant metabolites / extracts countering viral pathogens Current knowledge and future prospects. Current Drug Metabolism 19(3):236-263.
Dhama K, Khan S, Tiwari R, Sircar S, Bhat S, Malik YS, Singh KP, Chaicumpa W, Bonilla-Aldana DK, Rodriguez-Morales AJ (2020) Coronavirus Disease 2019-COVID-19. Clinical Microbiology Reviews 33(4):e00028-20.

Dhama K, Saminathan M, Jacob SS, Singh M, Karthik K, Amarpal, Tiwari R, Sunkara LT, Malik YS, Singh RK (2015) Effect of immunomodulation and immunomodulatory agents on health with some bioactive principles, modes of action and potent biomedical applications. International Journal of Pharmacology 11(4): 253-290.

Divya M, Vijayakumar S, Chen J, Vaseeharan B, Durán-Lara EF (2020) A review of South Indian medicinal plant has the ability to combat against deadly viruses along with COVID-19?. Microbial Pathogenesis. https://doi.org/10.1016/j.micpath.2020.104277

Donma MM, Donma O (2020) The effects of allium sativum on immunity within the scope of COVID-19 infection. Med Hypotheses 144:109934. doi:10.1016/j.mehy.2020.109934

Elsayed Y, Khan NA (2020) Immunity-Boosting Spices and the Novel Coronavirus. ACS Chemical Neuroscience. DOI: 10.1021/acschemneuro.0c00239

Gangal N, Nagle V, Pawar Y, Dasgupta S (2020) Reconsidering Traditional Medicinal Plants to Combat COVID-19. AIJR Preprints 2020; https://preprints.aijr.org/index.php/ap/preprint/view/34

Ghosh R, Chakraborty A, Biswas A, Chowdhuri S (2020) Evaluation of green tea polyphenols as novel corona virus (SARS CoV-2) main protease (Mpro) inhibitors - an in silico docking and molecular dynamics simulation study. Journal of Biomolecular Structure and Dynamics 1-13. doi:10.1080/07391102.2020.1779818.

Gupta H, Gupta M, Bhargava S (2020) Potential use of Turmeric in COVID-19. Clinical and Experimental Dermatology 2020. Jul $1 ; 10.1111 /$ ced.14357.

Hlengwa N, Muller CJ, Basson AK, Bowles S, Louw J, Awortwe C (2020) Herbal supplements interactions with oral oestrogenbased contraceptive metabolism and transport. Phytotherapy Research. https://drhyman.com/blog/2020/03/17/protectyourselffrom-covid-19/.https://www.worldometers.info/coronavirus/.

Accessed on $26^{\text {th }}$ October, 2020.

Huang C, Wang Y, Li X, Ren L, Zhao J, Hu Y, Cheng Z (2020) Clinical features of patients infected with 2019 novel coronavirus in Wuhan, China. The Lancet 395(10223): 497-506.

Hyman M (2020) How to Protect Yourself from COVID-19: Supporting Your Immune System When You May Need It Most. Dr. 
Hyman. Retrieved 2 April 2020, from Mani JS, Johnson JB, Steel JC, Broszczak DA, Neilsen PM, Walsh https://drhyman.com/blog/2020/03/17/protectyourself-from-covid-19/.

Infusino F, Marazzato M, Mancone M, Fedele F, Mastroianni CM, Severino P, Ceccarelli G, Santinelli L, Cavarretta E, Marullo AGM, Miraldi F, Carnevale R, Nocella C, Biondi-Zoccai G, Pagnini C, Schiavon S, Pugliese F, Frati G, d'Ettorre G (2020) Diet Supplementation, Probiotics, and Nutraceuticals in SARS-CoV-2 Infection: A Scoping Review. Nutrients 12(6): E1718. doi: 10.3390/nu12061718

Jahan I, Onay A (2020) Potentials of plant-based substance to inhabit and probable cure for the COVID-19. Turkish Journal of Biology 44(3):228-241.

Join IFM, Calendar P (2020) Boosting Immunity: Functional Medicine Tips on Prevention \& Immunity Boosting During the COVID-19 (Coronavirus) Outbreak. Available at https://www.ifm.org/news-insights/boosting-immunity-functionalmedicine-tips-prevention-immunity-boosting-covid-19coronavirus-outbreak/ access on $2^{\text {nd }}$ October 2020.

Krupanidhi SK Abraham Peele TC, Venkateswarulu, Vijaya Sai Ayyagari, Md Nazneen Bobby, D John Babu, A Venkata Narayana, G Aishwarya (2020) Screening of phytochemical compounds of Tinospora cordifolia for their inhibitory activity on SARS-CoV-2: an in silico study. Journal of Biomolecular Structure and Dynamics 38:1-5.

Li Q, Guan X, Wu P, Wang X, Zhou L, Tong Y Xing X (2020a) Early transmission dynamics in Wuhan, China, of novel coronavirus-infected pneumonia. New England Journal of Medicine 382:1199-1207.

Li Y, Liu X, Guo L, Li J, Zhong D, Zhang Y, Clarke M, Jin R (2020b) Traditional Chinese herbal medicine for treating novel coronavirus (COVID-19) pneumonia: protocol for a systematic review and meta-analysis. Systematic Reviews 75(9): 1-6.

Mahima, Anu Rahal, Deb R, Latheef SK,Samad HA Tiwari R, Verma AK, Amit Kumar, Dhama K (2012) Immunomodulatory and Therapeutic Potentials of Herbal, Traditional/Indigenous and Ethnoveterinary Medicines. Pakistan Journal of Biological Sciences 15(16): 754-774.

Malik YS, Kumar N, Sircar S, Kaushik R, Bhat S, Dhama K, Gupta P, Goyal K, Singh MP, Ghoshal U, El Zowalaty ME, O R V, Yatoo MI, Tiwari R, Pathak M, Patel SK, Sah R, RodriguezMorales AJ, Ganesh B, Kumar P, Singh RK (2020) Coronavirus Disease Pandemic (COVID-19): Challenges and a Global Perspective. Pathogens 9(7):519.

Manayi A, Vazirian M, Saeidnia S (2015) Echinacea purpurea Pharmacology, phytochemistry and analysis methods. Pharmacognosy Reviews 9(17): 63-72.
KB, Naiker M. (2020) Natural product-derived phytochemicals as potential agents against coronaviruses: A review. Virus Research 284:197989.

Mekala P, Murthy TGK (2020) Phytochemical screening and pharmacological update on Kabasura Kudineer Choornam and Nilavembu Kudineer Choornam. Journal of Pharmacognosy and Phytochemistry 9(3): 1031-1036.

Ngwa W, Kumar R, Thompson D, Lyerly W, Moore R, Reid TE, Lowe H, Toyang N. (2020) Potential of Flavonoid-Inspired Phytomedicines against COVID-19. Molecules 25(11):2707. doi: 10.3390/molecules25112707.

Panyod S, Ho CT, Sheen LY (2020) Dietary therapy and herbal medicine for COVID-19 prevention: A review and perspective. Journal of Traditional and Complementary Medicine 10(4):420-427.

Peltzer K, Friend-du Preez N, Ramlagan S Fomundam H (2008) Use of traditional complementary and alternative medicine for HIV patients in KwaZulu-Natal, South Africa. BMC Public Health 8(1): 255.

Peng X, Xu X, Li Y, Cheng L, Zhou X, Ren B (2020) Transmission routes of 2019-nCoV and controls in dental practice. International Journal of Oral Science 12(1): 1-6.

Pitchiah Kumar M, Meenakshi Sundaram K, Ramasamy MS (2020) Coronavirus spike (S) glycoprotein (2019-ncov) targeted siddha medicines kabasura kudineer and thonthasura kudineer-in silico evidence for corona viral drug. Asian Journal of Pharmaceutical Research and Health Care 12: 20-27. DOI: https://doi.org/10.18311/ajprhc/2020/25103.

Quan FS, Compans RW, Cho YK, Kang, SM (2007) Ginseng and Salviae herbs play a role as immune activators and modulate immune responses during influenza virus infection. Vaccine 25(2): 272-282.

Rabi AF, Al Zoubi SM, Kasasbeh AG, Salameh MD, Al-Nasser DA (2020) SARS-CoV-2 and coronavirus disease 2019: What we know so far. Pathogens 9(3): 231.

Rahal A, Mahima, Verma AK, Kumar A, Tiwari R, Kapoor S, Chakraborty S, Dhama K (2014) Phytonutrients and nutraceuticals in vegetables and their multi-dimensional medicinal and health benefits for humans and their companion animals: A review. Journal of Biological Science 14(1): 1-19.

Rastogi S, Pandey DN, Singh RH (2020) COVID-19 Pandemic: A pragmatic plan for Ayurveda Intervention. Journal of Ayurveda and Integrative Medicine 2020; https://doi.org/10.1016/j.jaim.2020.04.002. 
Ren LL, Wang YM, Wu ZQ, Xiang ZC, Guo L, Xu T, Li H (2020) Identification of a novel coronavirus causing severe pneumonia in human: a descriptive study. Chinese medical journal 133(9): 10151024.

Rodriguez-Morales AJ, Bonilla-Aldana DK, Tiwari R, Sah R, Rabaan AA, Dhama K (2020) COVID-19, an emerging coronavirus infection: current scenario and recent developments an overview. Journal of Pure and Applied Microbiology 14(1): 0512. https://doi.org/10.22207/JPAM.14.1.02

Rothan HA, Byrareddy SN (2020) The epidemiology and pathogenesis of coronavirus disease (COVID-19) outbreak. Journal of Autoimmunity 109(6):102433.

Sandeep Varma R, Ashok G, Vidyashankar S, Patki P, Nandakumar KS (2011) Anti-inflammatory properties of Septilin in lipopolysaccharide activated monocytes and macrophage. Immunopharmacology and Immunotoxicology 33(1): 55-63.

Tiwari R, Dhama K, Sharun K, Iqbal Yatoo M, Malik YS, Singh R, Michalak I, Sah R, Bonilla-Aldana DK, Rodriguez-Morales AJ (2020) COVID-19: animals, veterinary and zoonotic links. Veterinary Quarterly 40(1):169-182. doi: 10.1080/01652176.2020.1766725.

Tiwari R, Latheef SK, Ahmed I, Iqbal H, Bule MH, Dhama K, Samad HA, Karthik K, Alagawany M, El-Hack ME, Yatoo MI, Farag MR (2018) Herbal Immunomodulators - A Remedial Panacea for Designing and Developing Effective Drugs and Medicines: Current Scenario and Future Prospects. Current Drug Metabolism 19(3): 264-301.
Tripathi MK, Singh P, Sharma S, Singh TP, Ethayathulla AS, Kaur $P$ (2020) Identification of bioactive molecule from Withania somnifera (Ashwagandha) as SARS-CoV-2 main protease inhibitor. Journal of Biomolecular Structure and Dynamics 1-14. DOI: 10.1080/07391102.2020.1790425.

Wan Y, Shang J, Graham R, Baric, RS, Li F (2020) Receptor recognition by the novel coronavirus from Wuhan: an analysis based on decade-long structural studies of SARS coronavirus. Journal of Virology 94(7): 1-9.

Wang W, Tang J, Wei F (2020) Updated understanding of the outbreak of 2019 novel coronavirus (2019-nCoV) in Wuhan. China. Journal of Medical Virology 92(4): 441-447.

Xu J, Zhang Y (2020) Traditional Chinese Medicine treatment of COVID-19. Complementary Therapies in Clinical Practice 39:101165.

Zhang L, Yu J, Zhou Y, Shen M, Sun L (2020b) Becoming a Faithful Defender: Traditional Chinese Medicine against Coronavirus Disease 2019 (COVID-19). American Journal of Chinese Medicine 48(4):763-777. doi: 10.1142/S0192415X2050038X.

Zhang Q, Wang Y, Qi C, Shen L, Li J (2020a) Clinical trial analysis of 2019-nCoV therapy registered in China. Journal of Medical Virology 92 (6): 540-545.

Zhu N, Zhang D, Wang W, Li X, Yang B, Song J, Niu P (2020) A novel coronavirus from patients with pneumonia in China, 2019. New England Journal of Medicine 382(8): 727-733. 